\title{
Monetary Policy Surprises, Positions of Traders, and Changes in Commodity Futures Prices
}

\author{
Nikolay Gospodinov and Ibrahim Jamali
}

\section{Working Paper 2013-12}

November 2013

\begin{abstract}
Using futures data for the period 1990-2008, this paper finds evidence that expansionary monetary policy surprises tend to increase crude and heating oil prices, and contractionary monetary policy shocks increase gold and platinum prices. Our analysis uncovers substantial heterogeneity in the magnitude of this response to positive and negative surprises across different commodities and commodity groups. The results also suggest that the positions of futures traders for the metals and energy commodities strongly respond to monetary policy shocks. The adjustment of the net long positions of hedgers and speculators appears to be a channel through which the monetary policy shocks are propagated to commodity price changes.
\end{abstract}

JEL classification: G13, G14, G17

Key words: commodity prices, monetary policy shocks, futures data, convenience yields, positions of traders, speculators, hedgers

The views expressed here are the authors' and not necessarily those of the Federal Reserve Bank of Atlanta or the Federal Reserve System. Any remaining errors are the authors' responsibility.

Please address questions regarding content to Nikolay Gospodinov, Research Department, Federal Reserve Bank of Atlanta, 1000 Peachtree Street N.E., Atlanta, GA 30309-4470, 404-498-7892, nikolay.gospodinov@atl.frb.org, or Ibrahim Jamali (contact author), Department of Finance, Accounting and Managerial Economics, Olayan School of Business, American University of Beirut, Beirut 1107 2020, P.0. Box 11-0236, Riad El-Solh Street, Lebanon, 961-1-340-460 (ext. 3770), ij08@aub.edu.lb.

Federal Reserve Bank of Atlanta working papers, including revised versions, are available on the Atlanta Fed's website at frbatlanta.org/pubs/WP/. Use the WebScriber Service at frbatlanta.org to receive e-mail notifications about new papers. 


\section{Introduction}

The surge in commodity prices in the mid-2000s has led to a renewed interest among policymakers, investors and academics in identifying the factors that drive commodity prices. While the inflationary consequences of commodity price increases and the adverse effect of oil price shocks on economic activity are widely studied by academics ${ }^{1}$ and articulated by policymakers (Bernanke, 2008), the factors driving commodity price fluctuations proved to be more difficult to uncover. Understanding the behavior of commodity prices is of key importance to designing economic policies that limit their impact on real economic activity and inflation. Factors that have been identified to drive the dynamics of spot commodity prices include convenience yields (Gospodinov and Ng, 2013), exchange rates (Chen, Rogoff and Rossi, 2010) and interest rates (Frankel, 2008).

The common view held by policymakers ascribes commodity price changes to commodity-specific demand and supply factors. For instance, Federal Reserve (Fed) Chairman Ben Bernanke (2011) states that "while supply and demand fundamentals surely account for most of the recent movements in commodity prices, some observers have attributed a significant portion of the run-up in prices to Federal Reserve policies, over and above the effects of those policies on U.S. economic growth." The Fed Chairman's remarks came amid widespread suggestions by pundits and the financial press $^{2}$ that the 2000 s commodity boom has been due, at least in part, to the loose monetary policy adopted by the Fed. Most notably, Hamilton (2009) argues that low short-term interest rates contribute to rising spot commodity prices by

\footnotetext{
${ }^{1}$ Despite the widely held view that commodity price increases pass-through to inflation, Gospodinov and $\mathrm{Ng}(2013)$ were the first to document a robust empirical relationship between commodity prices and inflation.

${ }^{2}$ See, for example, "Fed fuels commodity price spike", CNN money, November 30, 2011 and "Fed distances itself from high oil price", Financial Times, April 15, 2011.
} 
encouraging speculative trading activity and that changes in Federal funds futures are associated with changes in commodity prices. ${ }^{3}$

In this paper, we explore the effect of monetary policy on individual commodity prices from the metals and energy groups as well as on commodity price indexes. Using monthly commodity and interest rate futures data, we decompose the target rate changes into expected and surprise components and explore asymmetries in the response of commodity prices to the sign of the surprise component of Federal funds target rate changes. Our paper contributes to the literature along several lines. To the best of our knowledge, this is the first study to examine the response of individual commodities to monetary policy surprises. While a number of extant contributions examine the relationship between commodity prices and interest rates, ours is the first to decompose the target rate change into a surprise and an expected component. In view of the increasing financialization of commodities (Gorton and Rouwenhorst, 2006; Tang and Xiong, 2012; Buyuksahin and Robe, 2013), we argue that this distinction is of paramount importance from an efficient markets perspective according to which asset prices respond only to new information. In addition, we account for asymmetries in the response of commodity price changes to the sign of the Federal funds target rate surprise. Using data on positions of traders for individual commodities, our results also uncover a novel empirical relationship between the net long positions of commercial and noncommercial futures market participants and monetary policy surprises.

\footnotetext{
${ }^{3}$ More specifically, Hamilton (2009) remarks: "The sooner U.S. employment recovers, the sooner the Fed will start raising interest rates, and the sooner the game of putting borrowed cash into commodities would be up. For example, the implied fed funds rate on the September 2010 futures contract went from $0.5 \%$ on Thursday to $0.6 \%$ on Friday, consistent with the claim that interest rates have been an important factor in recent commodity price movements."
} 
Despite the voluminous literature on the effect of monetary policy changes on other financial variables such as interest rates (Kuttner, 2001), exchange rates (Fatum and Scholnick, 2008) and stock returns (Bernanke and Kuttner, 2005), the response of individual commodity prices to monetary policy shocks has not been thoroughly investigated in the literature. This is unfortunate given the increasingly important role that commodity prices play for aggregate inflation and output, asset allocation and investor sentiment. With the substantial heterogeneity across different individual commodities, commodity groups and different asset classes, it is difficult to conjecture if (the sign and the magnitude of) the documented response of other financial variables to monetary policy shocks would carry over to commodity prices. For example, commodity prices tend to be much more volatile than interest rates, exchange rates and stock prices with a wide range of volatility levels also within the commodity class. ${ }^{4}$ How much monetary policy surprises contribute to these vastly different volatilities would be undoubtedly of both academic as well as practical relevance for policy makers and investors.

Frankel (2008) relates surges in commodity prices to loose monetary policy followed by the Federal Reserve and other major central banks and provides empirical evidence of a negative relationship between real commodity prices and real interest rates. Anzuini, Lombardi and Pagano (2012) explore the effect of monetary policy on commodity prices and present empirical evidence suggesting that expansionary monetary policy leads to a modest increase in commodity prices. Gubler and Hertweck (2013) provide empirical evidence that an expansionary monetary

\footnotetext{
${ }^{4}$ For 2006, the annualized volatilities of 10 -year US Treasury note, Euro/Dollar exchange rate, S\&P 500 returns, crude oil, wheat, copper and natural gas were $3.8 \%, 7.2 \%, 9.7 \%, 26.4 \%, 29.5 \%, 38.5 \%$ and $62.2 \%$, respectively (Burghardt, 2008).
} 
policy shock results in a persistent increase in commodity prices. ${ }^{5}$ A parallel and closely related strand of the literature investigates the effect of announcements, defined more broadly, on commodity prices with somewhat mixed results (Frankel and Hardouvelis, 1985; Kilian and Vega, 2011).

Our paper differs from the extant and recent contributions to the literature along several dimensions. On the one hand, Frankel (2008) studies the effect of interest rate changes on individual commodity prices but does not distinguish between the expected and surprise components of such changes. On the other hand, several methodological differences distinguish our study from the interesting studies of Anzuini, Lombardi and Pagano (2012) and Gubler and Hertweck (2013). ${ }^{6}$ While the findings from recent studies that suggest a high-frequency response of energy prices to conventional and unconventional monetary policy are interesting and useful in many respects (Rosa 2012; Glick and Leduc, 2012; Basistha and Kurov, 2013), our paper examines a broader cross-section of commodities and presents evidence of a longer lived response of commodity prices to monetary policy which can be more informative from a policymaking and trading perspective. Our study also provides novel empirical evidence of an effect of monetary policy shocks on the positions of futures traders.

The rest of the paper is organized as follows. Section 2 presents a no-arbitrage model of commodity price determination which provides the theoretical foundation for our empirical specifications. Section 3 describes the construction of convenience yields, surprise and expected components of Federal Funds target rate changes as well as the speculating and hedging activity

\footnotetext{
5 In contrast, Frankel and Rose (2010) find little evidence of a relationship between real interest rates and commodity prices when convenience yields and risk are accounted for.

${ }^{6}$ For instance, we do not employ a vector autoregressive model (VAR) to identify monetary policy shocks. We also examine the effect of monetary policy on individual, rather than aggregate, commodity prices.
} 
measures. Section 4 reports the empirical results on the transmission of monetary policy surprises to commodity prices. Section 5 concludes.

\section{A No-Arbitrage Model of Commodity Price Determination}

The theoretical foundation for examining the effect of monetary policy on commodity prices rests on Frankel's (1986) seminal work that extends Dornbusch's (1976) exchange rate overshooting model to commodities and shows that, in the presence of price stickiness, agricultural commodity prices respond to interest rate changes. More recently, Frankel (2008) further generalizes this model and relates the difference between the futures and spot prices of a commodity, or the futures basis, to interest rates.

Changes in interest rates can, according to Frankel (2008), exert an impact on commodity prices through the inventories and speculation channels as well as by changing the incentives for extracting commodities. More specifically, Frankel (2008) argues that an increase in the interest rate increases firms' costs of carrying inventories and entices speculators to reallocate their portfolios. Following an interest rate increase, speculators would increase their holdings of Treasury bills, which become more attractive due to the higher interest rates, and decrease the share of commodities (or commodity futures contracts) in their portfolios. In addition, an increase in interest rate would increase the incentive to extract resources due to the increased opportunity cost of delaying extraction. Given the tight link between the Federal funds target rate, the Fed's main policy instrument, and various short-term interest rates, monetary policy actions can also affect commodity prices through the afore mentioned channels. 
However, modeling the relationship between the futures basis and interest rates predates Frankel's (2008) contribution. In fact, the theory of storage of Kaldor (1939) ${ }^{7}$ posits that the futures basis comprises two components: a forgone interest component from having to borrow and buy the commodity and a convenience yield component which measures the benefit accruing from holding the physical commodity. The benefit from holding the physical commodity does not accrue to the holder of a futures contract (see, for example, Brennan and Schwartz, 1985). ${ }^{8}$ In this section, we follow Gospodinov and $\mathrm{Ng}$ (2013) and provide a concise description of the noarbitrage model that relates commodity prices to convenience yields and interest rates.

Let $S_{j t}$ and $F_{j t}^{(n)}$ denote the spot and futures price of commodity $j$ for delivery at time $t+n$. Also, let $i_{t, n}$ be the risk-free rate between period $t$ and $t+n$ and $C Y_{j t}^{(n)}$ denote the (net of insurance and storage costs) marginal convenience yield over the period $t+n$ with the convention that $C Y_{j t}^{(0)}=0$. Fama and French (1987) provide an explicit relationship between the basis and the convenience yield:

$$
F_{j t}^{(n)}-S_{j t}=S_{j t} i_{t, n}-C Y_{j t}^{(n)}
$$

Furthermore, the theory of normal backwardation, first advanced by Keynes (1930), posits that investors who are long a futures contract earn a risk premium to compensate for the risk of

\footnotetext{
${ }^{7}$ See also Working (1948), Brennan (1958) and Tesler (1958). Deaton and Laroque (1992) provide a treatment of the theory of storage with no reference to futures markets. The theory of storage is also referred to as the cost-ofcarry model.

${ }^{8}$ Hull (2011) notes that possession of the physical commodity, unlike a futures contract, allows the owner to benefit from shortages and to keep production running. For instance, Hull (2011) argues that physical ownership of oil is unlikely to be regarded in the same manner as a futures contract for an oil refiner. Alternatively, Pindyck (1983) uses a rational commodity pricing model to show that the convenience yield can be viewed similarly to dividends on a stock. The negative of the convenience yield is also known as the interest-adjusted basis.
} 
fluctuations in the spot prices. In the presence of a time-varying risk premium, the futures basis can be expressed as:

$$
F_{j t}^{(n)}-S_{j t}=E_{t} S_{j t+n}-S_{j t}-\Psi_{j t}^{(n)}
$$

where $\Psi_{j t}^{(n)} \equiv E_{t} S_{j t+n}-F_{j t}^{(n)}$ denotes a time-varying risk premium. Equation (2) shows that the futures basis consists of a component related to expected spot price changes $E_{t} S_{j t+n}-S_{j t}$ as well as a risk premium component $\Psi_{j t}^{(n)}$.

Given that equations (1) and (2) are alternative formulations of the basis, they can be combined to provide a relationship between expected commodity price changes, the convenience yield and interest rates:

$$
E_{t} S_{j t+n}-S_{j t}=S_{j t} i_{t}-C Y_{j t}^{(n)}+\Psi_{j t}^{(n)}
$$

Let $c y_{j t}^{(n)}=C Y_{j t}^{(n)} / S_{j t}, \psi_{j t}^{(n)}=\Psi_{j t}^{(n)} / S_{j t}$ and $E_{t} \Delta^{(n)} s_{j t+\tau}=\left(E_{t} S_{j t+\tau}-S_{j t}\right) / S_{j t}$. Then,

$$
E_{t} \Delta^{(n)} s_{j t+\tau}=i_{t}^{(n)}+\psi_{j t}^{(n)}-c y_{j t}^{(n)}
$$

Equation (3) demonstrates that expected commodity spot price changes directly relate to the interest rate, the risk premium and the convenience yield. In the empirical counterpart of equation (3), we proxy the latent risk premium by observed variables such as hedging or speculating pressure and open interest growth (see footnote 18). Furthermore, we use futures data to decompose Federal funds target rate changes into a surprise and expected component and study the effect of monetary policy surprises on individual commodity prices as well as on two broad indexes of commodity prices. 


\section{Data and Variables}

\subsection{Commodity Prices and Convenience Yields}

Our data consist of monthly futures prices for commodities from the metals, energy, grains and oilseeds, livestock and meats, foodstuffs and industrial groups for the period January 1990 to November 2008. We additionally employ the Goldman Sachs and the Reuters/CRB commodity price indexes as broad measures of spot commodity prices. The Goldman Sachs commodity price index is chosen as a "tradable" benchmark for passive commodity investing." The starting and ending date of our sample are dictated by the availability of Federal funds futures and target rate data (further discussed in Section 3.2) used in computing the monetary policy shocks. ${ }^{10}$

The commodity prices for the nearest and next-to-nearest futures are obtained from the Commodity Research Bureau (CRB) at the daily frequency. Monthly prices for each commodity are obtained from daily data as the last observation of the month. We note that using end-ofmonth data is more consistent with the definition of the surprise and expected components of interest rates discussed in Section 3.2. Table A.1 in the Appendix provides information about each of the commodities used in the analysis. ${ }^{11}$ From the metals group, our analysis centers on gold, silver, platinum, and copper whereas crude and heating oil represent the energy group.

\footnotetext{
${ }^{9}$ Stoll and Whaley (2010) note that the Goldman Sachs index comprises commodities whose futures markets are deep and liquid thus making the index "tradable". Erb and Harvey (2006) discuss the CRB commodity index as another popular measure of aggregate commodity prices. We therefore employ these two indexes in our analysis. A third commonly used "tradable" commodity price index is the Dow Jones-UBS index. We do not employ the Dow Jones-UBS index due to limited data availability. Erb and Harvey (2006) note that, as of May 2004, the Goldman Sachs index accounts for $86 \%$ of combined total open interest of the three indexes while the CRB index accounts for $4 \%$ of total open interest.

${ }^{10}$ Federal funds futures started trading on the Chicago Board of Trade (CBOT) in October 1988. With the onset of the subprime mortgage crisis in 2007 and the ensuing decrease of the Federal funds rate towards the zero lower bound, the Federal funds target rate series was discontinued in mid-December 2008 and replaced by upper and lower bound target rate series.

${ }^{11}$ Table A.1 provides information regarding the commodity ticker, the commodity description, the futures exchange as well as the contract months.
} 
While examining the response of the change in the prices of the latter commodities to a monetary policy shock is the principal objective of the paper, we also examine the response of a broader cross-section of commodities drawn from the other groups. ${ }^{12}$

As is common in the literature (Fama and French 1987; Gospodinov and Ng, 2013), the nearest futures price is used to approximate spot commodity prices whereas the next-to-nearest contract is employed as the futures price. Monthly commodity price changes are constructed as the difference between the spot prices at the end of months $t$ and $t-1$ :

$$
\Delta s_{j t}=\frac{S_{j t}-S_{j t-1}}{S_{j t-1}} .
$$

In line with equation (1), the percentage net convenience yield for commodity $j$ is computed as:

$$
c y_{j t}^{(n)}=\frac{\left(1+i_{t}^{(n)}\right) S_{j t}-F_{j t}^{(n)}}{S_{j t}} .
$$

When computing the percentage net convenience yield, we use the three-month U.S. Treasury bill which is downloaded from Federal Reserve Economic Database (FRED) and adjusted for the time that separates the two futures contracts. In what follows, we suppress, for notational convenience, the dependence of convenience yields on the maturity period $n$.

The descriptive statistics for the commodity price changes and the percentage net convenience yields are presented in Table 1.

\section{[Insert Table 1 here]}

The summary statistics show that the bulk of commodity price changes are, on average, positive (exceptions are copper, coffee, orange juice, oats, wheat, lumber and live cattle). This, in turn,

\footnotetext{
${ }^{12}$ More specifically, we investigate the responses of all the commodities for which we can obtain a reliable record of positions of futures traders' data. These are cocoa, coffee, orange juice, sugar, corn, oats, soybeans, soybean oil, wheat, cotton, lumber, live and feeder cattle as well as lean hogs.
} 
suggests that commodity investors holding long futures positions, especially in the metals and energy groups, earned a positive risk premium over the sample period considered.

Commodity price changes exhibit little first-order autocorrelation. In contrast, convenience yields are persistent (with first-order autocorrelations ranging from 0.51 to 0.90 ). Convenience yields are, on average, positive for crude oil, copper and platinum and negative for gold, silver and heating oil. However, the large standard deviation of the convenience yields implies that the commodities considered can equally well be in contango or in backwardation. While the differences in the variability of the convenience yields is not pronounced across commodity groups, gold and silver exhibit much smaller variability than the remaining commodities.

\subsection{Surprise and Expected Components of Federal Funds Rate}

In this study, our interest lies in analyzing the effect of the interest rate at horizon $n=1, i_{t}^{(1)}=i$, which is related to the opportunity cost of buying and holding inventories. In particular, we are interested in the effect of Federal funds rate surprises on monthly commodity price changes. ${ }^{13}$ We proxy $i_{t}$ by the Federal funds target rate and construct monetary policy expected and surprise components from futures data.

Namely, we use Federal funds futures, officially known as thirty-day interest rate futures, to gauge the expected and surprise components of target rate changes. Federal funds futures are interest rate futures contracts that settle on the average of the month's overnight Federal funds

\footnotetext{
${ }^{13}$ In addition to having an appealing economic interpretation, working with changes of Federal funds rate and commodity prices helps us to circumvent some inference problems that arise from possible nonstationarity of these variables.
} 
rate. The contract is cash-settled daily (i.e. marked-to-market) and the initial contract size is five million dollars. Due to daily cash settlement and collateral requirements, default risk in Federal funds futures is negligible. Federal funds futures started trading on the Chicago Board of Trade (CBOT) in October 1988 where contracts with deliveries ranging from the current month to several months ahead exist. ${ }^{14}$

We follow Bernanke and Kuttner (2005) and define the monthly surprise as the difference between the average funds rate target for month $t$ and the one-month-ahead futures rate on the last day on month $t-1$ :

$$
\bar{\Delta} i_{t}^{u}=\frac{1}{D} \sum_{d=1}^{D} i_{t, d}-F_{t-1, D}^{(1)}
$$

where $i_{t, d}$ denotes the Federal funds target rate on day $d$ of month $t, F_{t-1, D}^{(1)}$ is the Federal funds futures rate from the last day of month $t-1$ and $D$ denotes the number of days in month $t$. The measure of the monthly expected component of a target rate change is computed as the difference between the futures rate on the last day of month $t-1$ and the Federal funds rate target on the last day of month $t-1$ :

$$
\bar{\Delta} i_{t}^{e}=F_{t-1, D}^{(1)}-i_{t-1, D}
$$

The constructed monthly surprise and expected components are regularly spaced and form typical time series to which time series methods can be applied.

\footnotetext{
${ }^{14}$ While contracts up to twelve months ahead exist, the liquidity typically drops sharply beyond the first six contracts. The one-month-ahead Federal funds futures contract we employ in this paper is highly liquid.
} 


\subsection{Positions of Futures Traders}

Frankel (2008) argues that an increase in interest rates can affect commodity prices by exerting an effect on the positions of traders. Specifically, an increase in interest rates would make Treasury bills more attractive to speculators relative to commodity contracts which, in turn, entices investors to decrease their holdings of commodity contracts in favor of Treasury bills. We therefore explore the effect of monetary policy shocks on positions of traders in order to study the transmission mechanism of monetary policy shocks to commodity prices.

As is customary in the literature, measures of speculating and hedging activity are constructed from data on commitment of traders (COT). COT reports for every commodity are provided by the U.S. Commodity Futures Trading Commission (CFTC). The CFTC requires traders with a position exceeding specific regulatory limits to report the details of their activities on a weekly basis. ${ }^{15}$ Namely, the CFTC classifies traders into commercial and noncommercial users of futures contracts. Extant and more recent contributions to the literature (Bessembinder, 1992; de Roon, Nijman and Veld, 2000; Szymanowska, de Roon, Nijman and van den Goorbergh, 2013; among others) consider commercial users of futures contracts to be traders or institutions using the futures contracts for hedging purposes. Traders or institutions falling into the noncommercial group are typically considered to be speculators (Schwarz, 2012). We note, in this context, that a number of studies (Ederington and Lee, 2002; Wang, 2003; Schwarz, 2012) acknowledge and discuss some difficulties that relate to classifying commercial users of futures

\footnotetext{
${ }^{15}$ These positions are referred to as reportable positions in COT reports. The CFTC notes that 70 to 90 percent of total open interest is accounted for by reportable positions in any given market. Weekly positions of traders data are available starting 1992 while semi-monthly data are available starting 1986 on the website of the CFTC.
} 
contracts as hedgers. ${ }^{16}$ Classifying noncommercial users as speculators has received a broader consensus in the literature (Ederington and Lee, 2002; Schwarz, 2012).

Notwithstanding the caveats relating to trader classification, we follow the literature by considering commercial users of futures contracts to be hedging and noncommercial users to be speculating. Following Dewally, Ederington and Fernando (2013), a measure of hedging pressure for month $t$ and commodity $j$ is constructed as the difference between long and short commercial positions as a percentage of total hedge positions:

$$
n l p_{j t}^{c}=100 \times \frac{\# \text { of long hedging positions }-\# \text { of short hedging positions }}{\text { total \# of hedge positions }} .
$$

A measure of speculating pressure, $n l p_{j t}^{n c}$, is constructed similarly to equation (8) by employing monthly noncommercial instead of commercial positions data. Using the constructed measures of hedging and speculating pressures, we examine the response of the positions of commercial and noncommercial futures traders to monetary policy shocks. The two types of traders might exhibit different responses to a monetary policy shock because of different risk tolerances or investment horizons. $^{17}$

The summary statistics for the net long commercial and noncommercial positions for the cross-section of commodities we consider in our analysis are reported in Panel B of Table 1. The descriptive statistics show that commercial users of a futures contract are, on average, net short (with the exception of feeder cattle) while noncommercial traders are, on average, net long (with

\footnotetext{
${ }^{16}$ Most notably, Ederington and Lee (2002) argue that some traders who are classified by the CFTC as commercial users in the heating oil futures market do in fact engage in speculative activities. A more detailed classification of traders is available in the disaggregated commitment of traders (DCOT) reports. The DCOT data is available starting 2006 on the CFTC's website. Using these data would, unfortunately, significantly limit our sample size.

${ }^{17}$ Institutional investors are more likely to be classified as commercial users of a futures contract and are thus more likely to have a longer investment horizon and lower risk tolerance than speculators. Their positions might therefore exhibit a smaller response to monetary policy shocks.
} 
the exception of cotton). Interestingly, the median net positions in the energy group tend to be smaller in magnitude than those of the metals group. In other words, Table 1 shows that hedging and speculating pressures are stronger for the precious metals than the energy commodities. The largest net long positions are, on average, those of silver and platinum. The first-order autocorrelation of the net long positions shows relatively high persistence with values ranging from 0.54 (heating oil net long noncommercial positions) to 0.87 (soybeans net long commercial positions).

\section{Econometric Methodology and Results}

\subsection{The Response of Commodity Price Changes to Monetary Policy Shocks}

Commodity prices are expected to respond differently to expansionary and contractionary monetary policy shocks. Consider first a negative monetary policy shock. An expansionary monetary policy shock, implying the Fed decreased the target rate more than expected by market participants, lowers the cost for speculators to use leverage and enter into commodity futures contracts positions (by lowering the opportunity cost of holding a margin account, for example) while simultaneously making Treasury bills less appealing. Similarly, an expansionary monetary policy shock would lower the cost of holding inventories for firms and the opportunity cost of not extracting resources today. A contractionary monetary policy shock, or a positive target rate surprise, would have the converse effect on commodity prices, speculating positions and holdings of inventories. Therefore, accounting for asymmetries with respect to the sign of the surprise allows us to more closely inspect the response of commodity price changes to monetary policy. 
Following a number of extant studies investigating asymmetries in the response of financial variables to monetary policy (see, for example, Basistha and Kurov, 2008), we examine the response of the commodity prices to positive and negative monetary policy surprises (contractionary and expansionary monetary policy) using the following equation:

$$
\Delta s_{j t+1}=\alpha+\beta^{e} \bar{\Delta} i_{t}^{e}+\beta^{u-} \bar{\Delta} i_{t}^{u} D\left(\bar{\Delta} i_{t}^{u}<0\right)+\beta^{u+} \bar{\Delta} i_{t}^{u} D\left(\bar{\Delta} i_{t}^{u} \geq 0\right)+\gamma c y_{j t}+\varepsilon_{t+1},
$$

where $D\left(\bar{\Delta} i_{t}^{u}<0\right)$ is a dummy (indicator) variable that takes the value one when the target rate surprise is negative and zero otherwise and $D\left(\bar{\Delta} i_{t}^{u} \geq 0\right)$ is a dummy variable taking the value one when the target rate surprise is positive and zero otherwise. Equation (9) relates commodity price changes to the signed surprise and expected components of a target rate change as well as to the convenience yields. ${ }^{18}$ The coefficient $\beta^{u-}$ gives the response of commodity price changes to negative target rate surprises (expansionary monetary policy) whereas the coefficient $\beta^{u+}$ measures the response of commodity price changes to positive target rate surprises (contractionary monetary policy).

The results from estimating equation (9) for the metals and energy commodities are reported in Panel A of Table 2.

\section{[Insert Table 2 here]}

The results reveal that while the prices of copper, heating and crude oil significantly increase following an expansionary monetary policy shock, the prices of gold and platinum increase

\footnotetext{
${ }^{18}$ Prior research suggests that commodity-specific variables contain predictive power and proxy for the latent risk premium. Hong and Yogo (2012) find that open interest growth is highly correlated with macroeconomic activity and contains information about future economic conditions that are not revealed by past commodity prices. Other studies find that hedging pressure possesses predictive power for commodity futures returns (Bessembinder, 1992; de Roon, Nijman and Veld, 2000; Szymanowska, de Roon, Nijman and van den Goorbergh, 2013). When we included the twelve-month change in the dollar commodity market interest (product of the nearest futures price and open interest) and hedging pressure, both variables were not found to be significant. We note that the insignificance of hedging pressure is in line with results reported by Wang (2003), Schwarz (2012) and Gorton, Hayashi and Rouwenhorst (2012).
} 
following a contractionary monetary policy shock. In particular, a 25 basis points negative target rate surprise leads to a statistically significant increase of 2.76 percentage points in the price of copper, 4.89 percentage points in the price of crude oil and 5.21 percentage points in the price of heating oil. The expansionary monetary policy shock also increases the prices of silver and gold, albeit the increase in the prices of these commodities is not significant.

The Goldman Sachs commodity price index responds significantly to expansionary monetary policy and the magnitude of the response is large, while the Reuters/CRB index's response to a Federal funds target rate surprise is of a smaller magnitude and significant only at the $10 \%$ level. Given that the Reuters/CRB contains a broader cross-section of commodities than those included in our analysis, the smaller magnitude of the response is possibly due to the confounding of the responses of several commodities and commodity groups (grains and oilseeds, livestock and meats, for example) to a monetary policy shock. ${ }^{19}$

In sum, the empirical results we obtain lend support to the hypothesis that monetary policy significantly affects the prices of some of the commodities in the energy and metals groups, albeit only a small fraction of commodity price variation can be attributed to monetary policy as evinced by the low $\mathrm{R}^{2}$. This is consistent with some existing studies in the literature (Anzuini, Lombardi and Pagano, 2012; Gubler and Hertweck, 2013) that provide evidence of an

\footnotetext{
${ }^{19}$ Glick and Leduc (2012), Stoll and Whaley (2010) and Buyuksahin and Robe (2013) note the Goldman Sachs commodity index is heavily weighted in favor of commodities in the energy group as these account for nearly $70 \%$ of the index. Unsurprisingly, the highly significant and large response of the Goldman Sachs index is similar to that of the energy commodities. Erb and Harvey (2006) discuss the composition of the CRB commodity price index and note that, prior to June 20, 2005 the index is constructed by geometric equal weighting. The different construction of the indexes and the equal weights assigned to all commodities in the CRB index is a potential explanation of the differential response to an expansionary monetary shock, reported in Table 2, of the Goldman Sachs and CRB indexes. The Goldman Sachs index can be viewed as being more "financialized" than the CRB index and therefore more responsive to monetary policy shocks. As we subsequently show in the paper, the response of the commodities from the grains and oilseeds, livestock and meats, industrial and foodstuffs groups to a monetary policy shock is not pronounced.
} 
increase in aggregate commodity prices following expansionary monetary policy. Nonetheless, these prior studies do not investigate the individual response of commodity prices to monetary policy and the results in Panel A of Table 2 illustrate an important element of heterogeneity in the responses of the individual commodities. While some commodities react strongly and significantly to expansionary monetary policy, other commodities tend to increase following a contractionary monetary policy shock.

Some remarks regarding the presence of asymmetries in the response of commodity prices to monetary policy are in order. The results in Panel A of Table 2 suggest that while the prices of precious metals generally increase due to a positive surprise, the prices of crude and heating oil decrease following the positive surprise. The observed heterogeneity in the responses of individual commodities and across commodity groups is expected a priori. We argue that such a differential response of commodity price changes to a monetary policy shock is partly due to the characteristics and potential uses of the individual commodities considered. For instance, when considering the metals group, gold is an investment commodity whereas copper has significant industrial uses. The responses of these commodities are therefore expected to be, at the outset, different.

A positive target rate surprise constitutes negative news to stocks whose cash flows (dividends) are valued at a higher than expected discount rate. Given the negative news to stocks stemming from the target rate surprise, investors seek different investments and turn to the relative safety of the precious metals. This, in turn, leads to an increase in price of the metals commodities. In addition, a positive target rate surprise signals an overheating economy and expectations of future increases in inflation. To the extent that precious metals act as hedges against inflation, the increase in the price of the precious metals can also result from increased 
demand by investors to hedge against higher inflation. On the other hand, the decrease in the prices of crude and heating oil can be attributed to an expected decrease in future output growth, a decrease in the desire to hold inventories by firms or to an increased incentive for extraction. In the next two sections, we provide an in-depth investigation of the channels of transmission of monetary policy shocks to energy and metals prices.

With the increasing financialization of commodities (Tang and Xiong, 2012; Buyuksahin and Robe, 2013), investors change their portfolio allocation between equities, fixed income securities and commodities. More specifically, a number of prior studies document a negative relationship between monetary policy surprises and stock returns (Bernanke and Kuttner, 2005; among others). A negative target rate surprise might therefore lead investors to increase the proportion of both investment commodities, namely gold and silver, and equities held in their portfolios. ${ }^{20}$

The sign of the target rate surprise also contains information regarding expected future economic activity. For instance, a negative monetary policy surprise implies that the Fed decreased the rate more than Federal funds futures market participants expect, and signals an attempt by the monetary authority to stimulate future economic activity. The expected increase in economic activity leads to a change in the price of commodities with significant industrial uses such as platinum, copper and crude oil (used as an input to production). We note that Fama and French (1988) provide evidence that the prices of gold, silver, copper and platinum vary significantly across the business cycle with large increases occurring before business cycle peaks and significant drops occurring thereafter. Given that monetary policy shocks also contain

\footnotetext{
${ }^{20}$ Our results might therefore imply asymmetries in the correlation between equities and commodities. Some commodities prices (copper, crude and heating oil) would be positively correlated with equities following an expansionary monetary policy shock while other commodity prices (gold and platinum) would negatively correlate with equity prices following a contractionary monetary policy shock. It would be interesting to examine such a hypothesis along the lines of the Buyuksahin and Robe's (2013) recent study. This is, however, beyond the scope of this paper.
} 
information about the future state of the business cycle, the significant response of metals prices to a monetary policy shock reported in Table 2 could be attributable to business cycle effects.

In this context, we note that Barsky and Kilian $(2002,2004)$ argue that monetary policy affects commodity prices indirectly through its effect on expectations of future inflation and output growth. While our results show that commodity prices are responsive to the monetary policy shock, they remain silent as to the exact channel through which monetary policy transmits to commodity prices. For example, it is plausible that the Fed increases the target rate more than market participants expect due to expectations of higher inflation. In order to better assess whether the response of commodity prices to monetary policy is due to the latter's indirect effect on inflation expectations, we re-estimate equation (9) using real rather than nominal commodity price changes. $^{21}$ The individual commodity prices as well the commodity price indexes are deflated by the seasonally adjusted U.S. consumer price index (all items) and commodity price changes are computed from real commodity prices as in equation (4).

The results from re-estimating equation (9) are reported in Panel B of Table 2. The results indicate that the significant effect of monetary policy surprises on energy and metals commodities is maintained when real commodity price changes are used instead of nominal commodity price changes. The response of some commodity price changes to monetary policy cannot, therefore, be solely ascribed to the latter's effect on inflation expectations. The results thus suggest that the transmission mechanism of monetary policy shocks to commodity prices appears to be more complex. To gain a better understanding of the transmission mechanism, we

\footnotetext{
${ }^{21}$ We note that using real commodity price changes is more in line with Frankel (2008).
} 
turn next to assessing the effect of expansionary monetary policy on convenience yields and the positions of futures traders.

\subsection{Convenience Yields and Monetary Policy Shocks}

The lack of a reliable record of historical inventory data for the commodities comprising our sample prevents us from exploring the direct relationship between inventories and monetary policy shocks. Instead, we opt for an alternative route to investigate the inventory channel of monetary policy transmission to commodities.

The theory of storage (Brennan, 1958; Tesler, 1958; Fama and French, 1987, 1988) postulates a negative relationship between the level of inventories and the marginal convenience yield on a commodity. A low convenience yield for a commodity indicates that the level of inventories is high. ${ }^{22}$ Intuitively, the availability of inventories for a commodity lowers the benefit that accrues from holding the inventory in stock. We follow Fama and French (1987, 1988) and proxy for the level of inventories using the marginal convenience yields. More specifically, the effect of a monetary policy shock on commodities is examined by employing the convenience yields as a dependent variable in equation (9) instead of the commodity price changes.

The results from estimating equation (9) with the convenience yields employed as a dependent variable are reported in Table 3.

\section{[Insert Table 3 here]}

\footnotetext{
${ }^{22}$ Gorton, Hayashi and Rouwenhorst (2012) provide empirical evidence of a negative and nonlinear relationship between the futures basis and inventories.
} 
Apart from crude and heating oil, the convenience yields do not display a significant response to a monetary policy shock. Our results therefore suggest that the incentives for extracting a commodity or holding inventories are not directly affected by the monetary policy stance. ${ }^{23}$

\subsection{Positions of Traders and Monetary Policy Shocks}

As previously noted, monetary policy actions can exert an effect on commodity prices through enticing traders to shift in or out of commodity futures contracts. We next examine one of the indirect channels through which monetary policy surprises can affect commodity prices. The availability of COT data allows for investigating the effect of monetary policy surprises on positions of traders. As argued earlier, an increase in the interest rate would make Treasury bills more appealing to speculators while simultaneously increasing their costs (say, for example, for using leverage) of holding onto commodity futures positions. It is therefore plausible that monetary policy affects commodity prices through its effect on the positions of traders in the commodity markets.

In order to further investigate such a transmission mechanism, we relate the net long positions of hedgers (commercial users) and speculators (noncommercial users) to the expected and surprise component of target rate changes. Equation (9) is re-estimated (with the convenience yield omitted as a regressor) with net long commercial and noncommercial positions used as a dependent variable in lieu of the change in commodity prices.

\footnotetext{
${ }^{23}$ This finding is consistent with the view regarding the role of inventories in the 2000's surge of commodity prices summarized by Bernanke (2011): "Another argument that has been made is that low interest rates have pushed up commodity prices by reducing the cost of holding inventories, thus boosting commodity demand... In fact, inventories of most commodities have not shown sizable increases over the past year as prices rose..."
} 
The results from estimating (9) with hedging or speculating pressure as a dependent variable are reported in Panels A and B of Table 4, respectively.

\section{[Insert Table 4 here]}

In line with Frankel's (2008) arguments, the results in Table 4 suggest a significant response of positions of traders to monetary policy surprises for most commodities. A closer inspection of the response of the two trader types reveals some additional interesting observations. Panel A indicates a highly significant (at the $1 \%$ level) decrease in the net long positions of hedgers (i.e. an increase in net short positions) following an expansionary monetary policy shock (negative surprise) for copper, gold, platinum and silver. The response of hedging pressure in the crude and heating oil markets is smaller in magnitude and statistically significant only at the $10 \%$ level. This, in turn, suggests that expansionary monetary policy decreases hedging pressure for the metals but exerts a smaller effect on the energy commodities.

The results in Panel B reveal that net long noncommercial positions (speculating pressure) significantly increase following a negative target rate surprise for all the commodities considered. The increase in the speculating pressure in the crude and heating oil markets is particularly striking given that the response of hedging pressure for these two commodities to expansionary monetary policy is smaller in magnitude. Our results therefore suggest that expansionary monetary policy entices speculators to enter into futures contracts. This finding is not surprising given that expansionary monetary policy decreases the cost of holding onto speculative positions while simultaneously making Treasury bills less appealing. The decreased cost of holding onto speculative positions yields an increase in speculating pressure. 
Acharya, Lochstoer and Ramadorai (2013) develop a theoretical model in which speculators are capital constrained due to margin requirements or value-at-risk limits. ${ }^{24}$ Our empirical results suggesting an increase in speculating pressure might therefore be attributable to an expansionary monetary policy shock's role in alleviating such capital constraints. This interpretation would concur with Acharya, Lochstoer and Ramadorai's (2013) theoretical and empirical accounts.

The results in Table 5 also suggest that, following an expansionary monetary policy shock, speculators appear to increase their (net long) positions more than hedgers increase their (net short) positions. ${ }^{25}$ The resulting net effect appears to be an increase in net long positions for every commodity. The seemingly greater sensitivity of the positions of speculators to a negative Federal funds target rate surprises possibly reflects a lower risk aversion and shorter investment horizon vis-à-vis hedgers. ${ }^{26}$ Speculators might therefore be more disposed than hedgers to increase their futures holdings in light of lower interest rates that alleviate their capital constraints. Dewally, Ederington and Fernando (2013) find that speculators earn statistically and economically significant profits while hedgers typically incur losses. It is therefore plausible that speculators respond more aggressively and are better disposed than hedgers to exploit a monetary policy easing to make additional profits.

An apparent reconciliation of the empirical findings in Tables 2 and 4 would be that an expansionary monetary policy shock drives commodity prices (copper, heating and crude oil) up by increasing net long noncommercial positions more than it increases hedgers' net short

\footnotetext{
${ }^{24}$ In line with their theoretical account, Acharya, Lochstoer and Ramadorai (2013) additionally provide empirical evidence suggesting that default risk affects commodity returns and increases the net short positions of hedgers.

${ }^{25}$ It is important to note that the long and short positions of commercial and noncommercial traders need not sum to zero. The positions of small traders (non-reportable in the CFTC classification of traders) ensure that the total short and long positions net out.

${ }^{26}$ Schwarz (2012) notes that traders whose positions arise from underlying business needs are more likely to be classified as commercial users (hedgers).
} 
positions. Using a unique dataset, Buyuksahin and Robe (2013) provide empirical evidence demonstrating that the increased correlation between commodity and equity returns is induced by cross-market participation of speculators (and more specifically, the activity of hedge funds). Drawing upon the findings of Buyuksahin and Robe (2013) and in line with Frankel's (2008) and our earlier arguments, it would be conceivable for expansionary monetary policy to entice speculators to increase their holdings of commodity and equity futures contracts simultaneously. This would imply, in turn, that an expansionary monetary policy shock would contribute to increasing both cross-market linkages and commodity prices through an easing of speculators' capital constraints (Acharya, Lochstoer and Ramadorai, 2013). ${ }^{27}$

However, providing a comprehensive interpretation of the evidence in Tables 2 and 4 proves to be a much more intricate task. Our empirical analysis examines the response of commodity price changes and positions of traders to monetary policy shocks separately and suggests that both variables respond to monetary policy shocks. The effect of monetary policy shocks on positions of traders is an indirect channel of transmission of monetary policy to commodity prices. In such a context, causal statements cannot be straightforwardly made and we do not claim the presence of a causal effect between the increase in speculative pressure and the increase in commodity prices. A vector autoregressive model where commodity prices, convenience yields, positions of traders and monetary policy are jointly modeled would be better suited for examining causality among the variables.

\footnotetext{
${ }^{27}$ Such an interpretation would draw upon and combine the existing empirical evidence. We unfortunately lack the non-public data used in Buyuksahin and Robe (2013) to test such a hypothesis directly. We attempt instead to explore this interesting hypothesis by re-estimating equation (9), excluding the convenience yield as a regressor, using the net long non-commercial positions for the S\&P 500 futures as a dependent variable. Interestingly, our results (available from the authors) suggest an expansionary monetary policy shock significantly (at the $5 \%$ level) increases speculative pressure in the S\&P 500 futures market.
} 


\subsection{The Effect of Monetary Policy Shocks on Other Commodity Prices}

While the emphasis of this paper revolves around the response of commodity prices from the metals and energy groups to monetary policy, we present in this section the response of a broader cross-section of commodities to monetary policy shocks. Examining the response of a larger number of commodities proves to be instructive in illustrating the heterogeneous effects of monetary policy on individual commodities.

Equation (9) is re-estimated for commodities in the livestock and meats, grains and oilseeds, foodstuffs and industrial groups.

\section{[Insert Table 5 here]}

The results, reported in Table 5, suggest that, unlike the commodities belonging to the metals and energy groups, expansionary monetary policy does not exert an impact on the prices of these commodities. Instead, the convenience yields have predictive power for these commodities, as documented in Gospodinov and $\mathrm{Ng}$ (2013). The significance of the convenience yield is consistent with the overriding importance of fundamentals (i.e. inventories) for these commodities.

The insignificant effect of monetary policy surprises on the price changes of foodstuffs, grains and oilseeds, livestock and meats and industrial commodities illustrates the heterogeneity in the responses of individual commodities to monetary policy shocks. The results are also in line with our earlier finding relating to the response of commodity price indexes. Namely, while the Goldman Sachs index, which is heavily weighted in favor of energy commodities, responds strongly to monetary policy shocks, the response of the Reuters/CRB index which weighs all commodities similarly is muted. This, in turn, is suggestive that monetary policy exerts an effect on the commodities that are either useful as hedges against inflation (such as metals) or whose 
price fluctuations importantly depend on the state of the business cycle. In fact, the results from estimating hedging or speculative pressure regressions (available from the authors upon request) for the commodities in the foodstuffs, grains and oilseeds, industrial and livestock and meats groups corroborate this conclusion as the effect of the monetary policy shock on the positions of non-commercial traders is scantly significant.

\subsection{Robustness Checks}

Computing the monetary policy shocks as in equation (6) allows us to circumvent the need to impose identifying assumptions within a vector autoregressive (VAR) model to recover the structural monetary policy shocks. Nonetheless, the monetary policy shocks computed in equation (6) suffer from a drawback. As noted in Bernanke and Kuttner (2005), these shocks may respond to macroeconomic news. We therefore investigate the robustness of our results by constructing a new monetary policy shocks series that is purged from economic news.

More specifically, we follow the extant literature by defining the unexpected (news) components in employment, industrial production and inflation as the difference between the Money Market Survey (MMS) as reported (or announced) and median forecast values. We then regress the monetary policy shocks in equation (6) on the economic news and retain the residuals from the regression as our new monetary policy shocks. This new series is, by construction, orthogonal to employment, industrial production and inflation news. Equation (9) is then reestimated with commodity price changes or net long positions as dependent variables and the purged monetary policy shocks as an independent variable. Reassuringly, the results (available from the authors upon request) suggest that the significance and magnitude of the effect of monetary policy shocks on commodity prices and net long positions of traders is maintained. 


\section{Concluding Remarks}

This paper investigates the effect of monetary policy shocks on commodity prices, convenience yields and positions of traders. Using Federal funds futures data to decompose target rate changes into surprise and expected components, our results reveal that expansionary monetary policy increases the prices of crude and heating oil while contractionary monetary policy increases gold and platinum prices. Our results also suggest the presence of substantial heterogeneities in the response to a monetary shock across commodities and commodity groups. While changes in the futures prices of precious metals and energy commodities appear to respond to Federal funds target rate surprises, the prices of individual commodities belonging to the other commodity groups do not respond to the monetary policy shock.

Our analysis also uncovers that the monetary policy stance strongly affects the positions of futures traders. An expansionary monetary policy shock uniformly increases (decreases) speculating (hedging) pressure for the metals and energy commodities and the adjustment of net long positions appears to be a channel through which monetary policy changes propagate to commodity prices. Further theoretical and empirical work on the transmission of monetary policy to commodity prices through its effect on positions of traders proves to be a promising direction for future research. 


\section{References}

Acharya, V.V., Lochstoer, L.A., Ramadorai, T., 2013. Limits to arbitrage and hedging: evidence from commodity markets. Journal of Financial Economics 109, 441-465.

Anzuini, A., Lombardi, M.J., Pagano, P., 2012. The impact of monetary policy shocks on commodity prices. Working paper No. 851, Bank of Italy.

Barsky, R., Kilian, L., 2002. Do we really know that oil caused the great stagflation? A monetary alternative. NBER Macroeconomics Annual 16, 137-183.

Barsky, R., Kilian, L., 2004. Oil and the macroeconomy since the 1970's. Journal of Economic Perspectives 18, 115-134.

Basistha, A., Kurov, A., 2008. Macroeconomic cycles and the stock market's response to monetary policy, Journal of Banking and Finance 32, 2606-2616.

Basistha, A., Kurov, A., 2013. The impact of monetary policy surprises on energy prices. Journal of Futures Markets, forthcoming.

Bernanke, B., 2008. Outstanding issues in the analysis of inflation. Speech at the Federal Reserve Bank of Boston's $53^{\text {rd }}$ Annual Economic Conference, Chatham, Massachusetts.

Bernanke, B., 2011. The U.S. economic outlook. Speech at the International Monetary Conference, Atlanta, Georgia.

Bernanke, B., Kuttner, K., 2005. What explains the stock market's reaction to Federal Reserve policy? Journal of Finance 60, 1221-1257.

Bessembinder, H., 1992. Systematic risk, hedging pressure, and risk premiums in futures markets. Review of Financial Studies 5, 637-667.

Brennan, M., 1958. The supply of storage. American Economic Review 48, 50-72.

Brennan, M. J., Schwartz, E., 1985. Evaluating natural resource investments. Journal of Business $58,135-157$.

Burghardt, G., 2008. Volume surges again: Global futures and options trading rises 28\% in 2007. Futures Industry Magazine, March/April, 15-26.

Buyuksahin, B., Robe, M.A., 2013. Speculators, commodities and cross-market linkages. Journal of International Money and Finance, forthcoming.

Chen, Y.C., Rogoff, K., Rossi, B., 2010. Can exchange rates forecast commodity prices? Quarterly Journal of Economics 125, 1145-1194.

Deaton, A., Laroque, G., 1992. On the behavior of commodity prices. Review of Economic Studies 59, 1-23. 
Dewally, M., Ederington, L.H., Fernando, C.S., 2013. Determinants of trader profits in commodity futures markets. Review of Financial Studies 26, 2648-2683.

Dornbusch, R., 1976. Expectations and exchange rate dynamics. Journal of Political Economy 84, 1161-1176.

de Roon, F.A., Nijman, T., Veld, C., 2000. Hedging pressure effect in futures markets. Journal of Finance 55, 1437-1456.

Ederington, L., Lee, J.H., 2002. Who trades futures and how: evidence from the heating oil futures market. Journal of Business 75, 353-373.

Fama, E., French, K., 1987. Commodity futures prices: some evidence on forecast power, premiums, and the theory of storage, Journal of Business 60, 55-73.

Fama, E., French, K., 1988. Business cycles and the behavior of metals prices, Journal of Finance 43, 1075-1093.

Fatum, R., Scholnick, B., 2008. Monetary policy and exchange rate responses: do only surprises matter? Journal of Banking and Finance 32, 1076-1086.

Frankel, J., 1986. Commodity expectations and commodity price dynamics: the overshooting model. American Journal of Agricultural Economics 68, 344-348.

Frankel, J., 2008. The effect of monetary policy on real commodity prices. In J. Campbell (Ed.) Asset Prices and Monetary Policy, University of Chicago Press, Chicago, 291-327.

Frankel, J., Hardouvelis, G., 1985. Commodity prices, money surprises and Fed credibility. Journal of Money, Credit and Banking 17, 425-438.

Frankel, J., Rose, A., 2010. Determinants of agricultural and mineral commodity prices. In R. Fry, C. Jones \& C. Kent (Eds.) Inflation in an Era of Relative Price Shocks, Reserve Bank of Australia.

Glick, R., Leduc, S., 2012. Central bank announcements of asset purchases and the impact on global financial and commodity markets. Journal of International Money and Finance 31, 2078-2101.

Gorton, G., Hayashi, F., Rouwenhorst, G.K., 2012. The fundamentals of commodity futures returns. Review of Finance 17, 35-105.

Gorton, G., Rouwenhorst, G.,K., 2006. Facts and fantasies about commodity futures. Financial Analysts Journal 62, 47-68.

Gospodinov, N., Ng, S., 2013. Commodity prices, convenience yields, and inflation. Review of Economics and Statistics 95, 206-219.

Gubler, M., Hertweck, M.S., 2013. Commodity price shocks and the business cycle: structural evidence for the US. Journal of International Money and Finance 37, 324-352. 
Hamilton, J.D., 2009. Commodity prices and the Fed. Econbrowser, December.

Hong, H., \& Yogo, M., 2012. What does futures market interest tell us about the macroeconomy and asset prices? Journal of Financial Economics 105, 473-490.

Hull, J., 2011. Options, Futures and Other Derivatives ( $8^{\text {th }}$ ed.), Prentice Hall.

Kaldor, N., 1939. Speculation and economic stability. Review of Economic Studies 7, 1-27.

Keynes, J. M., 1930. A Treatise on Money. Macmillan, London.

Kilian, L., Vega, C., 2011. Do energy prices respond to U.S. macroeconomic news? A test of the hypothesis of predetermined energy prices, Review of Economics and Statistics 93, 660671.

Kuttner, K., 2001. Monetary policy surprises and interest rates: Evidence from the Fed funds futures market. Journal of Monetary Economics 47, 523-544.

Newey, W., West, K., 1987. A simple, positive semi-definite, heteroskedasticity and autocorrelation consistent covariance matrix. Econometrica 55, 703-708.

Pindyck, R., 1993. The present value model of rational commodity pricing. Economic Journal 103, 511-530.

Rosa, C., 2013. The high-frequency response of energy prices to monetary policy: understanding the empirical evidence. Federal Reserve Bank of New York Staff Reports, Staff Report No. 598.

Schwarz, K., 2012. Are speculators informed? Journal of Futures Markets 32, 1-23.

Szymanowska, M., de Roon, F., Nijman, T., van den Goorbergh, 2013. An anatomy of commodity futures risk premia. Journal of Finance, forthcoming

Stoll, H.R., Whaley, R.E., 2010. Commodity index investing and commodity futures prices. Journal of Applied Finance 1, 1-40.

Tang, K., \& Xiong, W., 2012. Index investment and the financialization of commodities. Financial Analysts Journal 68, 54-74.

Tesler, L., 1958. Futures trading and the storage of cotton and wheat. Journal of Political Economy 66, 233-255.

Wang, C., 2003. The behavior and performance of major types of futures traders. Journal of Futures Markets 23, 1-31.

Working, H., 1949. The theory of the price of storage. American Economic Review 39, 12541262. 
TABLE 1. Descriptive statistics

Panel A: Commodity Prices and Convenience Yields

\begin{tabular}{|c|c|c|c|c|c|c|}
\hline & \multicolumn{3}{|c|}{$\Delta s_{j t}$} & \multicolumn{3}{|c|}{$c y_{j t}$} \\
\hline$j$ & med & s.d. & $A R$ & med & s.d. & AR \\
\hline Copper & -0.04 & 7.61 & 0.09 & 0.74 & 8.15 & 0.79 \\
\hline Gold & 0.13 & 4.21 & -0.12 & -0.03 & 0.17 & 0.61 \\
\hline Platinum & 0.48 & 5.84 & 0.14 & 0.92 & 1.09 & 0.80 \\
\hline Silver & 0.12 & 7.45 & -0.09 & -0.14 & 0.26 & 0.54 \\
\hline Crude Oil & 0.58 & 9.74 & 0.14 & 0.44 & 1.90 & 0.69 \\
\hline Heating Oil & 0.45 & 10.58 & 0.04 & -0.29 & 3.55 & 0.58 \\
\hline Cocoa & -0.23 & 9.20 & -0.21 & -0.97 & 1.84 & 0.64 \\
\hline Coffee & -0.65 & 11.49 & -0.02 & -1.80 & 3.67 & 0.90 \\
\hline Orange Juice & -0.29 & 9.04 & -0.09 & -1.28 & 2.97 & 0.75 \\
\hline Sugar & 0.22 & 9.53 & 0.03 & 0.80 & 5.49 & 0.57 \\
\hline Corn & 0.09 & 7.58 & 0.04 & -2.20 & 3.22 & 0.79 \\
\hline Oats & -0.54 & 8.90 & -0.04 & -2.56 & 5.00 & 0.71 \\
\hline Soybeans & 0.40 & 7.06 & -0.02 & -0.41 & 1.77 & 0.70 \\
\hline Soybean Oil & 0.50 & 7.49 & -0.09 & -0.42 & 1.10 & 0.82 \\
\hline Wheat & -0.23 & 7.98 & -0.04 & -2.05 & 3.48 & 0.76 \\
\hline Cotton & -0.13 & 8.66 & -0.13 & -1.42 & 4.33 & 0.58 \\
\hline Lumber & -0.52 & 10.30 & -0.11 & -1.29 & 4.71 & 0.57 \\
\hline Feeder Cattle & 0.11 & 4.09 & 0.05 & 0.72 & 1.72 & 0.55 \\
\hline Live Cattle & -0.26 & 4.69 & -0.01 & 0.80 & 3.72 & 0.56 \\
\hline Lean Hogs & 0.60 & 10.11 & -0.18 & -0.13 & 8.20 & 0.51 \\
\hline Goldman Sachs Index & 0.49 & 6.11 & 0.15 & - & - & - \\
\hline Reuters/CRB Index & 0.16 & 3.30 & 0.07 & - & - & - \\
\hline \multicolumn{7}{|c|}{ Panel B: Net Long Positions } \\
\hline & \multicolumn{3}{|c|}{$n / p_{j t}{ }^{c}$} & \multicolumn{3}{|c|}{$n l p_{j t}^{n c}$} \\
\hline$j$ & med & s.d. & $A R$ & med & s.d. & AR \\
\hline Copper & -10.80 & 20.78 & 0.74 & 12.70 & 45.00 & 0.72 \\
\hline Gold & -19.19 & 30.42 & 0.83 & 25.00 & 53.10 & 0.77 \\
\hline Platinum & -43.78 & 26.85 & 0.75 & 61.38 & 37.67 & 0.63 \\
\hline Silver & -49.37 & 15.46 & 0.64 & 61.58 & 28.10 & 0.58 \\
\hline Crude Oil & -1.12 & 5.79 & 0.63 & 7.28 & 35.58 & 0.59 \\
\hline Heating Oil & -6.97 & 7.71 & 0.62 & 16.48 & 41.90 & 0.54 \\
\hline Cocoa & -8.50 & 12.55 & 0.83 & 15.96 & 43.61 & 0.75 \\
\hline Coffee & -14.02 & 14.68 & 0.56 & 22.88 & 39.08 & 0.60 \\
\hline Orange Juice & -19.68 & 24.46 & 0.78 & 20.10 & 42.22 & 0.67 \\
\hline
\end{tabular}




\begin{tabular}{l|ccc|ccc|} 
Sugar & -13.57 & 17.59 & 0.70 & 39.97 & 48.78 & 0.67 \\
\hline Corn & -0.36 & 14.81 & 0.78 & 30.45 & 41.67 & 0.73 \\
Oats & -38.52 & 16.79 & 0.68 & 60.25 & 33.55 & 0.65 \\
Soybeans & -14.54 & 20.61 & 0.87 & 35.32 & 41.24 & 0.82 \\
Soybean Oil & -15.04 & 18.56 & 0.75 & 29.30 & 47.79 & 0.74 \\
Wheat & -9.97 & 18.15 & 0.77 & 6.68 & 32.32 & 0.72 \\
\hline Cotton & -2.54 & 20.47 & 0.70 & -4.32 & 53.00 & 0.70 \\
Lumber & -15.42 & 41.49 & 0.70 & 9.31 & 38.50 & 0.61 \\
\hline Feeder Cattle & 18.25 & 24.28 & 0.75 & 22.33 & 31.60 & 0.70 \\
Live Cattle & -5.02 & 12.95 & 0.80 & 39.85 & 55.29 & 0.64 \\
Lean Hogs & -0.22 & 21.55 & 0.62 & 16.14 & 32.54 & 0.70 \\
\hline
\end{tabular}

Notes: The table provides the median, standard deviations and first-order autocorrelations for the commodity price changes $\left(\Delta s_{j t}\right)$, convenience yields $\left(c y_{j t}\right)$, net long commercial positions $\left(n l p_{j t}^{c}\right)$ as well as net long noncommercial positions $\left(n l p_{j t}^{n c}\right)$ for individual commodities and spot commodity price indexes used. The sample period is January 1990 to November 2008. 
TABLE 2 . The response of energy and metals commodities to monetary policy shocks

\begin{tabular}{|c|c|c|c|c|c|}
\hline \multicolumn{6}{|l|}{ Panel A: Nominal Commodity Prices } \\
\hline commodity & $\bar{\Delta} i_{t}^{e}$ & $\bar{\Delta} i_{t}^{u} D\left(\bar{\Delta} i_{t}^{u}<0\right)$ & $\bar{\Delta} i_{t}^{u} D\left(\bar{\Delta} i_{t}^{u} \geq 0\right)$ & $c y_{j t}$ & $R^{2}$ \\
\hline \multirow[t]{2}{*}{ Copper } & 5.62 & $11.05^{* * *}$ & $-26.69 * * *$ & -0.18 & 0.03 \\
\hline & $(4.63)$ & (3.69) & $(9.36)$ & $(0.19)$ & \\
\hline \multirow[t]{2}{*}{ Gold } & -3.15 & 3.17 & $14.04 * *$ & 0.53 & 0.02 \\
\hline & (3.38) & (3.41) & $(6.45)$ & $(2.25)$ & \\
\hline \multirow[t]{2}{*}{ Platinum } & -1.81 & -2.02 & $23.02 * * *$ & $0.75^{*}$ & 0.03 \\
\hline & (3.64) & $(5.12)$ & $(8.06)$ & $(0.42)$ & \\
\hline \multirow[t]{2}{*}{ Silver } & -1.66 & 3.34 & 11.71 & $-3.39 *$ & 0.02 \\
\hline & $(4.21)$ & $(5.81)$ & $(13.88)$ & $(2.01)$ & \\
\hline \multirow[t]{2}{*}{ Crude Oil } & 1.26 & $19.59 * * *$ & -13.58 & -0.55 & 0.04 \\
\hline & $(6.47)$ & $(6.53)$ & $(22.90)$ & $(0.33)$ & \\
\hline \multirow[t]{2}{*}{ Heating Oil } & 3.92 & $20.85^{* * *}$ & -15.41 & $-0.53 * * *$ & 0.06 \\
\hline & $(5.86)$ & $(5.34)$ & $(15.85)$ & $(0.19)$ & \\
\hline \multirow[t]{2}{*}{ Goldman Sachs Commodity Index } & 0.43 & $11.10^{* * *}$ & -9.48 & - & 0.02 \\
\hline & (3.97) & (3.69) & $(11.51)$ & - & \\
\hline \multirow[t]{2}{*}{ Reuters/CRB Commodity Index } & -0.07 & $3.38 *$ & -3.87 & - & 0.00 \\
\hline & $(1.97)$ & $(1.95)$ & $(3.34)$ & - & \\
\hline \multicolumn{6}{|l|}{ Panel B: Real Commodity Prices } \\
\hline commodity & $\bar{\Delta} i_{t}^{e}$ & $\bar{\Delta} i_{t}^{u} D\left(\bar{\Delta} i_{t}^{u}<0\right)$ & $\bar{\Delta} i_{t}^{u} D\left(\bar{\Delta} i_{t}^{u} \geq 0\right)$ & $c y_{j t}$ & $R^{2}$ \\
\hline \multirow{2}{*}{ Copper } & 5.20 & $10.70 * * *$ & $-26.16 * * *$ & -0.20 & 0.03 \\
\hline & $(4.55)$ & (3.70) & $(9.18)$ & $(0.18)$ & \\
\hline \multirow[t]{2}{*}{ Gold } & -3.69 & 2.76 & $14.59 * *$ & 0.40 & 0.03 \\
\hline & (3.55) & (3.52) & $(6.93)$ & $(2.16)$ & \\
\hline \multirow[t]{2}{*}{ Platinum } & -2.38 & -2.35 & $23.57^{* * *}$ & $0.74 *$ & 0.03 \\
\hline & $(3.74)$ & $(5.18)$ & $(8.16)$ & $(0.40)$ & \\
\hline \multirow[t]{2}{*}{ Silver } & -2.22 & 2.93 & 12.53 & -3.27 & 0.02 \\
\hline & $(4.27)$ & $(5.91)$ & $(14.41)$ & $(2.01)$ & \\
\hline \multirow[t]{2}{*}{ Crude Oil } & -0.86 & $16.66 * * *$ & 28.77 & $-0.70 * *$ & 0.05 \\
\hline & $(5.85)$ & $(5.91)$ & $(20.51)$ & $(0.35)$ & \\
\hline \multirow[t]{2}{*}{ Heating Oil } & 1.99 & $18.35^{* * *}$ & 19.44 & $-0.60 * * *$ & 0.06 \\
\hline & (5.79) & $(5.03)$ & $(19.11)$ & $(0.18)$ & \\
\hline \multirow[t]{2}{*}{ Goldman Sachs Commodity Index } & -0.04 & $10.77^{* * *}$ & -9.01 & - & 0.02 \\
\hline & $(3.82)$ & (3.58) & $(10.62)$ & - & \\
\hline \multirow[t]{2}{*}{ Reuters/CRB Commodity Index } & -0.59 & 3.05 & -3.33 & - & 0.00 \\
\hline & $(1.84)$ & $(2.02)$ & (3.21) & - & \\
\hline
\end{tabular}


Notes: The table provides the results from estimating the regression:

$$
\Delta s_{j t+1}=\alpha+\beta^{e} \bar{\Delta} i_{t}^{e}+\beta^{u-} \bar{\Delta} i_{t}^{u} D\left(\bar{\Delta} i_{t}^{u}<0\right)+\beta^{u+} \bar{\Delta} i_{t}^{u} D\left(\bar{\Delta} i_{t}^{u} \geq 0\right)+\gamma c y_{j t}+\varepsilon_{t+1},
$$

where $\bar{\Delta} i_{t}^{e}$ is the expected component of the Federal funds target rate change, $\bar{\Delta} i_{t}^{u}$ is the surprise component of the target change and $c y_{j t}$ is the convenience yield for commodity $j$. Newey and West (1987) heteroskedasticity and autocorrelation consistent (HAC) standard errors with automatic lag length and bandwidth selection are reported in parentheses. * denotes statistical significance at the $10 \%$ level, ** at the $5 \%$ level and $* * *$ at the $1 \%$ level. 
TABLE 3. The response of convenience yields to monetary policy shocks

\begin{tabular}{l|ccc|c|}
\hline \hline commodity & $\bar{\Delta} i_{t}^{e}$ & $\bar{\Delta} i_{t}^{u} D\left(\bar{\Delta} i_{t}^{u}<0\right)$ & $\bar{\Delta} i_{t}^{u} D\left(\bar{\Delta} i_{t}^{u} \geq 0\right)$ & $R^{2}$ \\
\hline \multirow{2}{*}{ Copper } & $5.21^{* * *}$ & 0.69 & 1.28 & 0.06 \\
Gold & $(1.47)$ & $(1.52)$ & $(4.10)$ & \\
& 0.13 & $-0.48^{* * *}$ & -0.04 & 0.06 \\
Platinum & $(0.16)$ & $(0.12)$ & $(0.23)$ & 0.01 \\
Silver & -0.58 & 1.29 & -2.70 & \\
& $(1.22)$ & $(0.85)$ & $(2.30)$ & 0.02 \\
\hline Crude Oil & 0.15 & $0.38^{* *}$ & -0.72 & 0.03 \\
& $(0.14)$ & $(0.16)$ & $(0.54)$ & \\
Heating Oil & 1.02 & -1.92 & $13.68 *$ & 0.03 \\
& $(1.36)$ & $(2.21)$ & $(8.15)$ & $21.43^{* *}$ \\
\hline
\end{tabular}

Notes: The table provides the results from estimating the regression:

$$
c y_{j t+1}=\alpha+\beta^{e} \bar{\Delta} i_{t}^{e}+\beta^{u-} \bar{\Delta} i_{t}^{u} D\left(\bar{\Delta} i_{t}^{u}<0\right)+\beta^{u+} \bar{\Delta} i_{t}^{u} D\left(\bar{\Delta} i_{t}^{u} \geq 0\right)+\varepsilon_{t+1},
$$

where $\bar{\Delta} i_{t}^{e}$ is the expected component of the Federal funds target rate change and $\bar{\Delta} i_{t}^{u}$ is the surprise component of the target change. Newey and West (1987) heteroskedasticity and autocorrelation consistent (HAC) standard errors with automatic lag length and bandwidth selection are reported in parentheses. ${ }^{*}$ denotes statistical significance at the $10 \%$ level, ${ }^{*}$ at the $5 \%$ level and $* * *$ at the $1 \%$ level. 
TABLE 4. The response of net long positions to monetary shocks

\begin{tabular}{l|ccc|c}
\hline \hline \multicolumn{5}{l|}{ Panel A: Commercial Net Long Positions } \\
\hline \hline commodity & $\bar{\Delta} i_{t}^{e}$ & $\bar{\Delta} i_{t}^{u} D\left(\bar{\Delta} i_{t}^{u}<0\right)$ & $\bar{\Delta} i_{t}^{u} D\left(\bar{\Delta} i_{t}^{u} \geq 0\right)$ & $R^{2}$ \\
\hline Copper & $-58.04^{* * *}$ & $-45.38^{* *}$ & 3.27 & 0.10 \\
Gold & $(15.78)$ & $(17.55)$ & $(52.79)$ & \\
& 16.09 & $-100.63^{* * *}$ & -18.86 & 0.08 \\
Platinum & $(28.94)$ & $(25.26)$ & $(56.62)$ & \\
& -32.44 & $-84.43^{* * *}$ & -39.98 & 0.08 \\
Silver & $(31.44)$ & $(18.26)$ & $(52.99)$ & \\
& -10.91 & $-32.90^{* * *}$ & 16.23 & 0.03 \\
\hline Crude Oil & $(12.27)$ & $(11.74)$ & $(30.80)$ & \\
Heating Oil & $-11.66^{*}$ & $-9.04^{*}$ & 8.90 & 0.05 \\
& $(6.08)$ & $(5.24)$ & $(12.84)$ & \\
\hline \hline Panel B: Non-Commercial Net Long Positions & -2.31 & $-9.64^{*}$ & 15.24 & 0.01 \\
commodity & $(6.81)$ & $(5.75)$ & $(17.81)$ & \\
\hline Copper & \multicolumn{5}{|c}{} & \\
& $\bar{\Delta} i_{t}^{e}$ & $\bar{\Delta} i_{t}^{u} D\left(\bar{\Delta} i_{t}^{u}<0\right)$ & $\bar{\Delta} i_{t}^{u} D\left(\bar{\Delta} i_{t}^{u} \geq 0\right)$ & $R^{2}$ \\
Gold & $90.33^{* * *}$ & $117.95^{* * *}$ & -1.08 & 0.08 \\
& $(32.26)$ & $(44.41)$ & $(100.83)$ & \\
Platinum & -45.86 & $172.83^{* * *}$ & 68.61 & 0.09 \\
Silver & $(43.51)$ & $(39.46)$ & $(97.69)$ & \\
& $50.85^{* *}$ & $113.45^{* * *}$ & 52.98 & 0.08 \\
\hline Crude Oil & $(24.08)$ & $(41.41)$ & $(62.39)$ & \\
& 16.62 & $35.58^{*}$ & -11.89 & 0.01 \\
Heating Oil & $(27.06)$ & $(20.47)$ & $(55.88)$ & \\
\hline & $96.46^{* * *}$ & $80.27^{* * *}$ & -68.29 & 0.10 \\
& $(35.48)$ & $(25.67)$ & $(73.98)$ & \\
& -14.78 & $63.98^{* *}$ & -74.96 & 0.01 \\
& $(50.18)$ & $(31.94)$ & $(107.93)$ & \\
\hline
\end{tabular}

Notes: The table provides the results from estimating the regressions:

$$
n l p_{j t+1}=\alpha+\beta^{e} \bar{\Delta} i_{t}^{e}+\beta^{u-} \bar{\Delta} i_{t}^{u} D\left(\bar{\Delta} i_{t}^{u}<0\right)+\beta^{u+} \bar{\Delta} i_{t}^{u} D\left(\bar{\Delta} i_{t}^{u} \geq 0\right)+\varepsilon_{t+1},
$$

where $\bar{\Delta} i_{t}^{e}$ is the expected component of the Federal funds target rate change and $\bar{\Delta} i_{t}^{u}$ is the surprise component of the target change. Newey and West (1987) heteroskedasticity and autocorrelation consistent (HAC) standard errors with automatic lag length and bandwidth selection are reported in parentheses. * denotes statistical significance at the $10 \%$ level, $* *$ at the $5 \%$ level and $* * *$ at the $1 \%$ level. 
TABLE 5. The response of grains and oilseeds, foodstuffs, industrial and livestock and meats commodities to monetary policy shocks

\begin{tabular}{|c|c|c|c|c|c|}
\hline commodity & $\bar{\Delta} i_{t}^{e}$ & $\bar{\Delta} i_{t}^{u} D\left(\bar{\Delta} i_{t}^{u}<0\right)$ & $\bar{\Delta} i_{t}^{u} D\left(\bar{\Delta} i_{t}^{u} \geq 0\right)$ & $c y_{j t}$ & $R^{2}$ \\
\hline \multirow[t]{2}{*}{ Cocoa } & $-22.39 * * *$ & 0.91 & 0.81 & $-0.78 * *$ & 0.06 \\
\hline & $(7.16)$ & (6.10) & $(16.22)$ & $(0.35)$ & \\
\hline \multirow[t]{2}{*}{ Coffee } & 5.92 & 6.96 & 5.07 & -0.06 & 0.00 \\
\hline & (7.89) & (5.89) & (21.03) & $(0.20)$ & \\
\hline \multirow[t]{2}{*}{ Orange Juice } & 6.50 & 9.07 & $-22.70^{*}$ & $-0.67 * * *$ & 0.06 \\
\hline & $(4.88)$ & $(6.41)$ & $(12.54)$ & $(0.17)$ & \\
\hline \multirow[t]{2}{*}{ Sugar } & 4.32 & 2.68 & -5.39 & $-0.59 * * *$ & 0.12 \\
\hline & $(6.63)$ & $(5.67)$ & $(10.60)$ & $(0.16)$ & \\
\hline \multirow[t]{2}{*}{ Corn } & -1.21 & -1.86 & 19.56 & $-0.59 * * *$ & 0.07 \\
\hline & (3.17) & (3.76) & (17.97) & (0.13) & \\
\hline \multirow[t]{2}{*}{ Oats } & -1.88 & -0.34 & 17.00 & -0.23 & 0.02 \\
\hline & $(5.92)$ & $(5.82)$ & $(12.02)$ & $(0.14)$ & \\
\hline \multirow[t]{2}{*}{ Soybeans } & $-5.90 *$ & 1.99 & -0.14 & $-1.16^{* * *}$ & 0.09 \\
\hline & (3.29) & (3.28) & $(12.64)$ & $(0.29)$ & \\
\hline \multirow[t]{2}{*}{ Soybean Oil } & 0.10 & -3.29 & 5.09 & -0.97 & 0.02 \\
\hline & $(5.08)$ & (4.61) & (8.10) & (0.59) & \\
\hline \multirow[t]{2}{*}{ Wheat } & 4.27 & -5.12 & $24.85^{*}$ & $-0.49 * * *$ & 0.05 \\
\hline & $(3.47)$ & $(5.87)$ & $(12.75)$ & $(0.10)$ & \\
\hline \multirow[t]{2}{*}{ Cotton } & 3.03 & -1.85 & 8.37 & $-0.67 * * *$ & 0.10 \\
\hline & (6.32) & (6.08) & (15.08) & (0.14) & \\
\hline \multirow[t]{2}{*}{ Lumber } & -1.08 & -9.77 & $-44.65 * * *$ & $-0.69 * * *$ & 0.11 \\
\hline & $(6.87)$ & $(8.45)$ & $(16.08)$ & $(0.11)$ & \\
\hline \multirow[t]{2}{*}{ Feeder Cattle } & 2.43 & -1.00 & 0.76 & $-0.84 * * *$ & 0.12 \\
\hline & (3.18) & $(2.63)$ & $(5.67)$ & (0.19) & \\
\hline \multirow[t]{2}{*}{ Live Cattle } & 2.41 & -1.48 & -1.60 & $-0.54 * * *$ & 0.18 \\
\hline & $(2.20)$ & $(2.33)$ & $(7.00)$ & $(0.07)$ & \\
\hline \multirow[t]{2}{*}{ Lean Hogs } & 0.59 & -7.29 & -6.03 & $-0.68 * * *$ & 0.29 \\
\hline & (6.08) & (5.53) & (17.97) & (0.09) & \\
\hline
\end{tabular}

Notes: The table provides the results from estimating the regression:

$$
\Delta s_{j t+1}=\alpha+\beta^{e} \bar{\Delta} i_{t}^{e}+\beta^{u-} \bar{\Delta} i_{t}^{u} D\left(\bar{\Delta} i_{t}^{u}<0\right)+\beta^{u+} \bar{\Delta} i_{t}^{u} D\left(\bar{\Delta} i_{t}^{u} \geq 0\right)+\gamma c y_{j t}+\varepsilon_{t+1},
$$

where $\bar{\Delta} i_{t}^{e}$ is the expected component of the Federal funds target rate change, $\bar{\Delta} i_{t}^{u}$ is the surprise component of the target change and $c y_{j t}$ is the convenience yield for commodity $j$. Newey and West (1987) heteroskedasticity and autocorrelation consistent (HAC) standard errors with automatic lag length and bandwidth selection are reported in parentheses. * denotes statistical significance at the $10 \%$ level, ** at the $5 \%$ level and $* * *$ at the $1 \%$ level. 
TABLE A.1: Commodity description

\begin{tabular}{|c|c|c|c|c|}
\hline Description & & Exchange & Contract Size & Contract Months \\
\hline \multicolumn{5}{|l|}{ Metals } \\
\hline HG & Copper High Grade/ Scrap No.2 & NYMEX & 25,000 lbs. & $\mathrm{H}, \mathrm{K}, \mathrm{N}, \mathrm{U}, \mathrm{Z}$ \\
\hline GC & Gold & NYMEX & 100 troy ounces & $G, J, M, Q, V, Z$ \\
\hline PL & Platinum & NYMEX & 50 troy ounces & $\mathrm{F}, \mathrm{J}, \mathrm{N}, \mathrm{V}$ \\
\hline SI & Silver & NYMEX & 5,000 troy ounces & $\mathrm{H}, \mathrm{K}, \mathrm{N}, \mathrm{U}, \mathrm{Z}$ \\
\hline \multicolumn{5}{|l|}{ Energy } \\
\hline $\mathrm{CL}$ & Crude Oil, WTI/ Global Spot & NYMEX & 1,000 barrels & $\mathrm{F}-\mathrm{Z}$ \\
\hline $\mathrm{HO}$ & Heating Oil No.2 / Fuel Oil & NYMEX & 42,000 gallons & $\mathrm{F}-\mathrm{Z}$ \\
\hline \multicolumn{5}{|l|}{ Foodstuffs } \\
\hline CC & Cocoa / Ivory Coast & NYBOT & 10 metric tons & $\mathrm{H}, \mathrm{K}, \mathrm{N}, \mathrm{U}, \mathrm{Z}$ \\
\hline KC & Coffee 'C' / Columbian & NYBOT & 37,500 lbs. & $H, K, N, U, Z$ \\
\hline JO & Orange Juice, Frozen Concentrate & NYBOT & 15,000 lbs. & $F, H, K, N, U, X$ \\
\hline SB & Sugar \# 11 / World Raw & NYBOT & $112,000 \mathrm{lbs}$. & $\mathrm{H}, \mathrm{K}, \mathrm{N}, \mathrm{V}$ \\
\hline \multicolumn{5}{|c|}{ Grains and Oilseeds } \\
\hline $\mathrm{C}-$ & Corn / No.2 Yellow & СВOT & $5,000 \mathrm{bu}$. & $\mathrm{F}, \mathrm{H}, \mathrm{K}, \mathrm{N}, \mathrm{U}, \mathrm{X}, \mathrm{Z}$ \\
\hline O- & Oats / No.2 White Heavy & СВOT & $5,000 \mathrm{bu}$. & $\mathrm{H}, \mathrm{K}, \mathrm{N}, \mathrm{U}, \mathrm{Z}$ \\
\hline S- & Soybeans / No.1 Yellow & СBOT & $5,000 \mathrm{bu}$. & $\mathrm{F}, \mathrm{H}, \mathrm{K}, \mathrm{N}, \mathrm{Q}, \mathrm{U}, \mathrm{X}$ \\
\hline BO & Soybean Oil / Crude & СВОТ & $60,000 \mathrm{lbs}$. & $F, H, K, N, Q, U, V, Z$ \\
\hline W- & Wheat / No.2 Soft Red & CBOT & $5,000 \mathrm{bu}$. & $\mathrm{H}, \mathrm{K}, \mathrm{N}, \mathrm{U}, \mathrm{Z}$ \\
\hline \multicolumn{5}{|l|}{ Industrials } \\
\hline CT & Cotton / 1-1 /16" & NYBOT & 50,000 lbs. & $\mathrm{H}, \mathrm{K}, \mathrm{N}, \mathrm{V}, \mathrm{Z}$ \\
\hline LB & Lumber / Spruce Pine Fir $2 \times 4$ & $\mathrm{CME}$ & $110,000 \mathrm{brd}$. feet & $F, H, K, N, U, X$ \\
\hline \multicolumn{5}{|c|}{$\begin{array}{l}\text { Livestock and } \\
\text { Meats }\end{array}$} \\
\hline FC & Feeder Cattle / Average & CME & 50000 lbs. & $F, H, J, K, Q, U, V, X$ \\
\hline LC & Live Cattle / Choice Average & CME & $40,000 \mathrm{lbs}$. & $G, J, M, Q, V, Z$ \\
\hline LH & Lean Hogs & CME & $40,000 \mathrm{lbs}$. & $G, J, M, N, Q, V, Z$ \\
\hline \multicolumn{5}{|c|}{ Commodity Indexes } \\
\hline GI & Goldman Sachs Commodity Index & $\mathrm{CME}$ & 250 USD*index & $G, J, M, Q, V, Z$ \\
\hline $\mathrm{Cl}$ & Reuters/CRB Index & NYBOT & 500 USD*index & $F, G, J, M, Q, X$ \\
\hline
\end{tabular}

Notes: This table contains information about each commodity used in the analysis. It lists the symbol (ticker), description, futures exchange where the commodity is traded, contract size and contract months. The notation for the futures exchanges is NYMEX - New York Mercantile Exchange, NYBOT - New York Board of Trade, CBOT - Chicago Board of Trade and CME - Chicago Mercantile Exchange. The symbols for futures contract months are $\mathrm{F}=$ January, $\mathrm{G}=$ February, $\mathrm{H}=\mathrm{March}, \mathrm{J}=$ April, $\mathrm{K}=\mathrm{May}, \mathrm{M}=$ June, $\mathrm{N}=$ July, $\mathrm{Q}=$ August, $\mathrm{U}=$ September, $\mathrm{V}=$ October, $\mathrm{X}=$ November and $\mathrm{Z}=$ December. The data source is the Commodity Research Bureau (CRB). 